(16)

\title{
高速度カメラを含む高精度歩行分析システムによる 足部を中心とする下肢機能の解析
}

（労災義肢センター）森本正治・笠原富美雄・土屋和夫

\section{1. まえがき}

一般に，義足の動的举動は，人間と同じであること が理想である. 下肢義肢において，特に下腿義足にお いて，その動的誉動に大きな影響を与える因子として， アライメントと共に, 足関節を含む足部機能があり， 義足設計上の大きなポイントである。この義足足部 （足関節を含む）機能設計のための重要な情報である， 立䐚初期での Foot-Flap を防ぐなめらかな接地を行 うための足関節まわりの底背屈モーメントのパターン， 立脚中期での，なめらかな体重移動のための足部の踵 や母指球，小指球の沈及具台，立脚後期での Push off における最適な踩り出しのパワーとタイミングを可能 にする足関節モーメントのパターンやつま先部の変形 パターンなどは, 人間の動的挙動の計测，すなわち， 歩行分析から得るのが，莪足歩行の数式モデルによる 方法なとに較へて，直接的かつ確実である.

ところが，従来の歩行分析で，下肢麻疩患者の回 復過程を追跡する臨床診断や，処方した義足の評洒を 目的としたものが大部分であり，健常者に較へて患者 や切断者の，床反力，床反力作用点軌跡，関節角度な どか，どの上うなパターンであるが概略的に観察す ることに重点が通かれていた：そのため，時間，垩用， 労力などの制約から上限が押えられて、データのサン プリング率は 10〜20[Hz］であり"，高速度サンプリ ングと称する場合でも50〜60[Hz] であった2).

莪足の設計の基礎資料を得るために下肢の歩行分析 を行ら場合には，上述の場台とは異なり，足部の動的 药形過程に関する情報を詳細に得るためにも，また， 2 階の数值微分を含む演算により関節モーメントを推 定するためにも，高精度の步行分析から得られる，よ り精密な運動学的扰よび力学的データが必要である.
本研究では, 最大 $500[$ ママ/秒] の高速度カメラに 同期した歩行分析システムを新しく開発し，主として 平坦路歩行時の, 立脚期間中の足部を中心とする下肢 の動的挙動を，健常者および義足装着者について計測 した，健常者データより，義足の満足すべき最終目標 を明らかにし，義足装着者のデータより，従来の義足 が，どの程度，人間の動的な举動をシミニレートでき ているかの比較を行った. 結果を、スティック・ピク チャー, 下肢関節の空間軌跡, 下肢関節角度, および 下肢関節モーメントについて整理して述べる. 特に, 下肢関節角度については，新しく，微小振動の現象が 钼察されたので，その原因を考察し，義足の性能評価 との閣連について述べ。.

\section{2. 実験システムおよび実験方法}

\section{1 高精度歩行分析システム}

新しく開発した步行分析システムの概要を図1に示 す. 主として，平坦路上を自然な歩速で歩行する被験 者の, 矢状面 ( $X-Z$ 平面) 内の立脚期の挙動に関し て, 床反力計により, 前後方向床反力 $F_{X}$ および 4 籄 所の支柱に作用する釷直床反力 $F_{Z_{1}} \sim F_{Z 4}$ を計測す る. 計算により， $F_{Z_{1}} \sim F_{Z 4}$ の合力として垂直床反力 $F_{Z}$ をまた，モーメントのつりあい点として床反力 作用点轨跡 (ZMP) を求める. 一方, 因 2 K示す下肢 標点の座摽を，16 mm 高速度カメラ (Photo Sonics 社製 1PL)により，主として 200[コマ/秒]で撮影し て、モーションアナライザーにかけて， Digitizer に 上り数值データに変換する.

三として 200[こマ/秒]を用いた理由は，撮影後の フィルム解析に要する時間, 労力を考えると 200 400 [こマ/秒] が上限であること，および，10〜50[こマ/ 


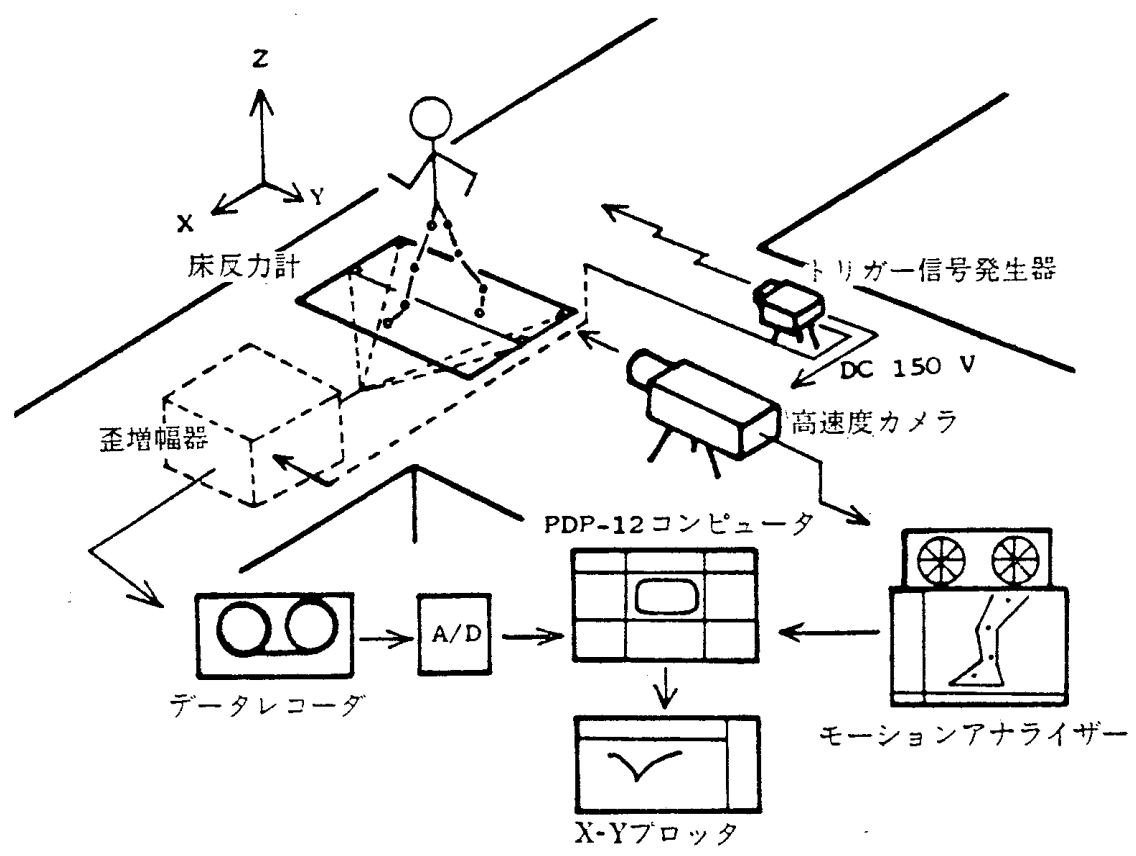

图 1 高精度步行分析システム。

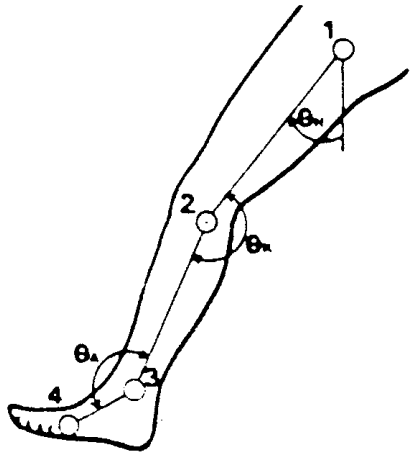

1 一大転子

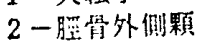

3-腓等外柴

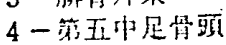

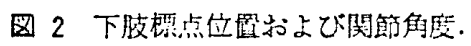

秒了では詳細な举動をとら兄るのが不可能であり(付録 参照), 少なくとも 100〜200[こマ/秒] 以上のサンプ リング离が必要なことによる.

高速度カメラと床反力計の同期は，反射型光電りレ ーにより床反力計直前の被䣖者を娭出して, トリガー 信号を双方へ送ることで行った。同期愦差は，200[Hz] での計測の照合， 1 こマ以内であった，床反力計より 求めた床反力作用点軌跡の空間坐磦との対応をつける ため，床反力計上にマーキング・テープを貼付け，こ れを参照点として高速度カメラで掫剭した。

\section{2 テータ奶理方法}

䗬動学的データから，各関節の空間軌跡および関節 角度の計算を行い，さらに，力学的データおよび運動 学的データから，下肢の㴊体りンクモデルに基ついて， 下肢関節部の反力およびモーメントを計算する。その

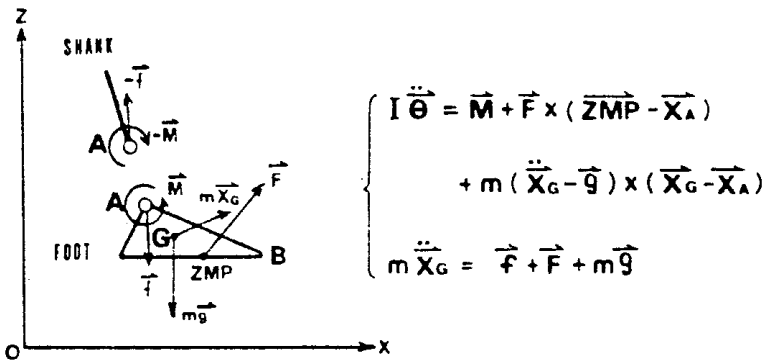

图 3 㓮体リンクモデルに菱づく関節モーメントの計年 (足関節の場合).

$\vec{F}:$ 外力， $\vec{X}:$ 位霓へクトル， $A:$ 足関節， $B:$ 小指球， $G:$ 足部血心， $I:$ 垂心ま初りの性性モーメント， $m:$ 足

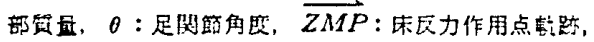

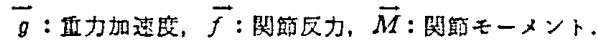

過程を図 3 に示す．生体パラメータ(セグメント重量， 重心位置，慣性モーメントなど）は，被娩者の身長， 体重，セグメント長からの推定㑑を用いぶ3.4)。運動 学的データの実寸法への换算は，フィルム上に写し込 んたスケールを読むことにより行った．数伹敒分は， デジタル微分フィルタらをを用いた，最終結果はすべ て，図出よびグラフとして，XーYプトッタ上へ出力 させた。

\section{3 被 験 者}

被験者は，片侧大腿切断 $(A / K)$, 片侧下腿切断 (B/ K) 各 2 名，健常者 (Normal) 3 名で，年齡 25〜 40 藏の男子である(表1参照). 1人の被験者につき， 
（16）高速度カメラを含む高精度步行分析システムによる足部を中心とする下肢機能の解析

表 1 被娩者.

\begin{tabular}{|c|c|c|c|}
\hline \multirow{3}{*}{ NORMAL } & A & 左 右 & 裸足 \\
\hline & $\mathrm{B}$ & " & " \\
\hline & $\mathrm{C}$ & " & " \\
\hline \multirow{2}{*}{$\mathrm{A} / \mathrm{K}$} & $\mathrm{D}$ & $\begin{array}{l}\text { 美足 } \\
\text { 健足 }\end{array}$ & 单軸足 \\
\hline & $E$ & $\begin{array}{l}\text { 義足 } \\
\text { 煡足 }\end{array}$ & 単軸足, SACH 足 \\
\hline \multirow{2}{*}{$\mathrm{B} / \mathrm{K}$} & $\mathrm{F}$ & $\begin{array}{l}\text { 義足 } \\
\text { 健足 } \\
\end{array}$ & GREISSINGER 足 \\
\hline & $\mathrm{G}$ & $\begin{array}{l}\text { 義足 } \\
\text { 健足 }\end{array}$ & 単軸足 \\
\hline
\end{tabular}

左右各 2 回ずつの計測を行った.

\section{3. 結果および考察}

高速度カメラによる運動学的データから求めた, 下 肢のスティック・ピクチャー，下肢関節の空間軌跡お よび下肢関節角度について述べる. 次に,これと，床 反力計から得た力学的データとから求めた下肢関節モ ーメントについて述べ, 最後に, 新たに観察された, 歩行中の立脚期に打ける走関節角度の微小振動现象に ついて，義足評価との関連において述べる.

\section{1 下肢のスティック・ピクチャー}

健常者および大腿切断者の義足側，健足侧の下肢の スティック・ピクチャーを運動学的データから再橉成 したものを図 4 に示す. 同一時刻での下肢各標点（困 2 参照)を直線で結んで下肢を表わしてある. 200[Hz] データと $20[\mathrm{~Hz}]$ データとを比較すれば，明らかに， 20[Hz] データからは下肢の詳細な動的挙動をとらえ にくいことがかかる，200[Hz]データから，健常者お よび大腿切断者健足侧の腅関節に，立脚中期で小さな 上下動が見られる.これは，大眼と下眼のセク゚メント 長が変化しているのではなく，㮏関節標点を貼付けた 皮店か，骨格に対して，筋収縮の影響をうけて相対変 位するためで岕ると考えられる。

これらの 200[Hz] データからは，足部付近の立脚 中期における線図の重なりがはなはたしく，判別しに くいところがある. そこで，次に示す空間軌跡，関節 角度で表わすことを試みた。

\section{2 下肢関節の空間軌跡}

スティック・ピクチャーでは判别しにくい，足関節 および小指球（図 2 の標点 3,4 ) の動きを, 空間軌跡と 乙て図 5 に示市. 大眼切断者義足側, 下腿切断者義足 側および健常者について比較した．200[Hz]データに よれば，遊脚から立脚への移行において健常者は，接 朱時の床となす角度がささく滑らかにヒール・コンタ クトが行われるが，大煺切断者の義足侧では，その角 度が 90 度以上あり，接踵時の㮏折れを防止するため に足部を後方へ引きるどしながらヒール・コンタクト を行っている樣子が観察されるままた，下腿切断者の 義足側は，接床時の床となす角度が健常者と大腿切断 者義足側との中間にあることを示している.しかし， 20[Hz] のデータからは, 詳細な学動をとらえること は困難である.

同様の空間軌跡について，単軸足装着の大腿切断者 の義足側にみられた現象を図 6 に示方．接踵時に，足 関節の軌跡がバウンドしている様子が，200[Hz]デー タから判別できる，20[Hz] データからでは，このよ らな現象はとら兄られない。バウンドの原因の1つは， 足部に用いる粘弾性材料の選択を愦ったことによると 考えられる。

\section{3 下肢関節角度}

大腿切断者の義足侧，健足側，および健常者につい $\tau$, 股関節角度 $\left(\theta_{H}\right)$, 橰関節解度 $\left(\theta_{K}\right)$, 足関節角度 $\left(\theta_{A}\right)$ の立脚期の動的挙動を図 7 に示す. 20[Hz]デ 一タは, 200[Hz]データの上ヘシフトさせて示してあ る. $200[\mathrm{~Hz}]$ データより, 下肢関節角度の微細な挙動 が把握できる、特に, 遊脚期から立脚期への邆移䢛程 での足関節角度の動きに関して，健常者は，接床後， 直ちに足関節を底背屈させているが，大腿切断者の健 足倒，義足侧は，ゆるやかな変動を示している.

健常者について, $\theta_{A}$ かi， $\theta_{K}, \theta_{H}$ に較へてて, 微小振 動成分の大きいことが雉察される，足関節角度 $\theta_{A}$ の 比較では，大腿切断者健足侧か，健常者，大腿切断者 の義足侧に較べて大きな微小振動成分を持っているこ とがわかる。

この微小振動については, 振幅が士 2 度以内と小さ いので, $16 \mathrm{~mm}$ フィルムをモーション・アナライザー にかけて標点座標をデジタル化する祭の, 人間の,カ ーソルによる読取りの誤差によるるのであることが考 

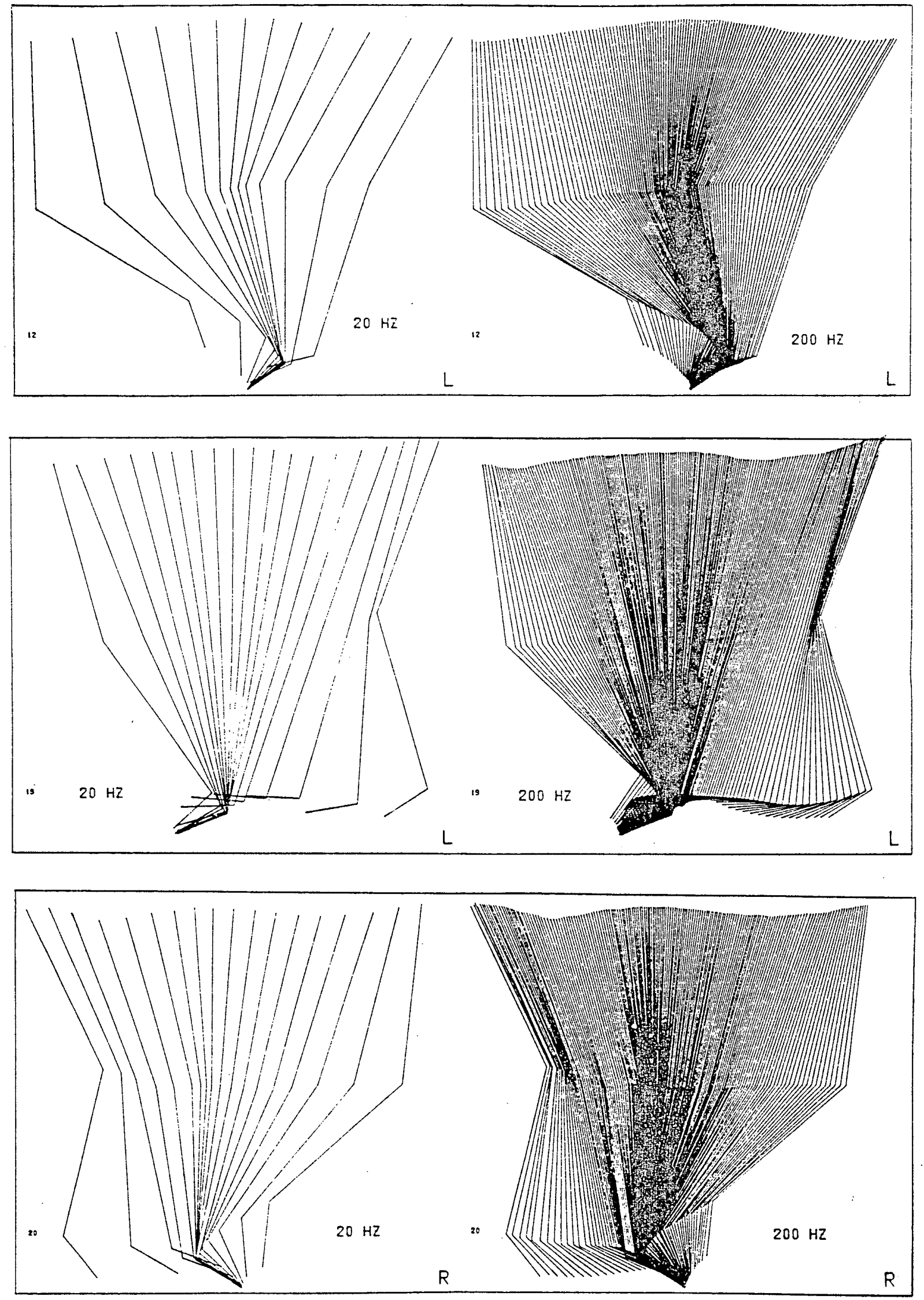

目 4 下肢のスティック・ピクチャー

（上）健常者，(中）大腿切断 $(\mathrm{A} / \mathrm{K})$ 義足侧，(下）大腿切断 $(\mathrm{A} / \mathrm{K})$ 践足側. 


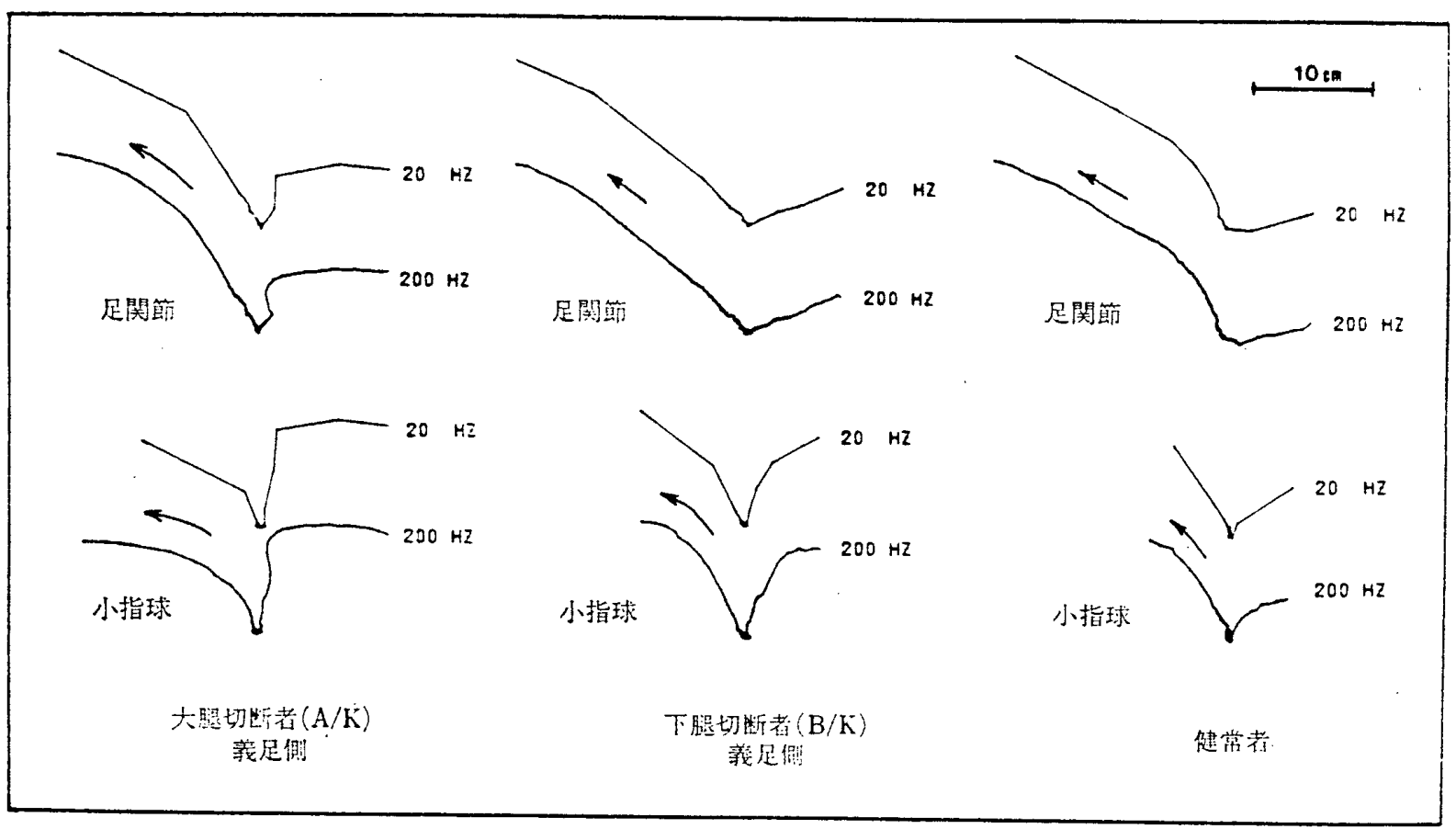

图 5 下肢骠点の空間軌跡.

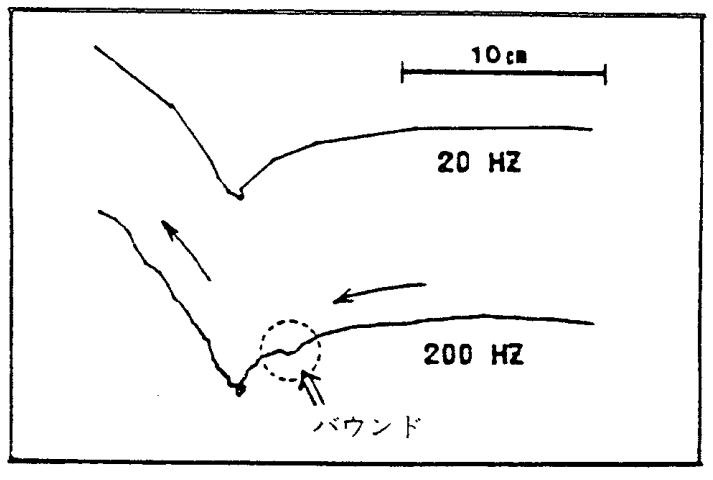

目 6 大腿切断者義足側足関節の空間軌跡.
吕られる、各標点の読取り精度が同じなら，関節角度 の計算精度はセグメント長に比例するので，足関節角 度は他の角度の 3 倍の変動まで誤差とみなせるが，そ れ以上の変動がある. また，大腿切断者の健足侧と義 足侧とで，足関節の微小振動に明確な差が存在するこ とからも，足関節角度の測定誤差は，少なくとも，大 腿切断者の義足側の微小振動成分より小さいことが塞 付けられ，足関節角度の微小振動が確かに存在すると 考えられる，足関節角度の微小振動の原因については， 3.5 節で, 義足評価と関連つけて考察する.
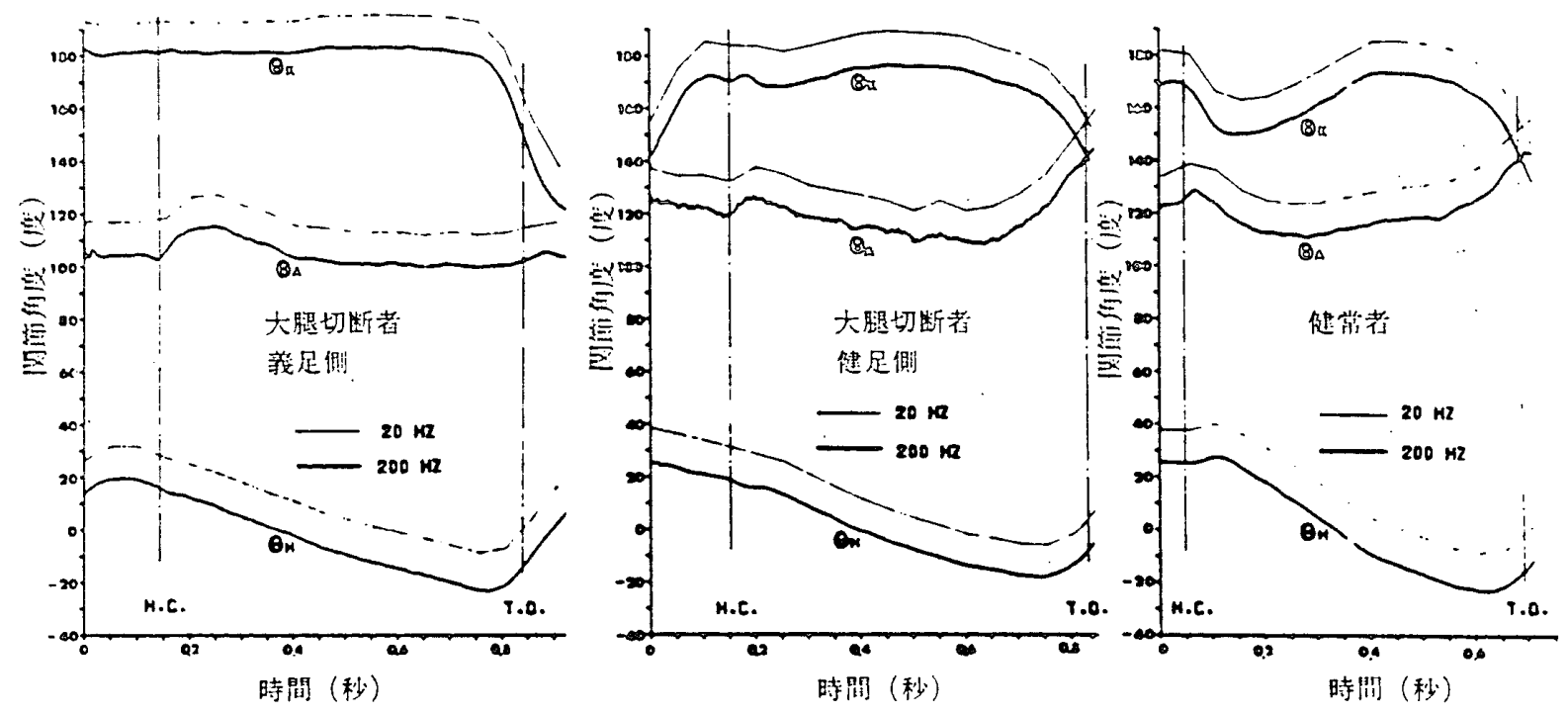

图 7 下肢関節角度の立脚期における变化. 


\section{4 下肢関節モーメント}

大腿切断者の義足側と健常者との足関節モーメント $\left(M_{A}\right)$ の比較を図 8 亿示す. 図中の䍃線は $20[\mathrm{~Hz}] テ ゙$ ータを，太線は200[Hz]データを示方２00[Hz]デ 一タから，足関節モーメントの動的挙動を詳細に把握 することができる，健常者は，接踵（H.C.）時に，底 背屈モーメントのバランスを保って, Foot Flap を防 いでなめらかな接地を可能にしている，それに較べて， 大腿切断者の義足側は，接床，離床 (T.O.) 時に, 垂 直床反力波形に振動がみられこれれか足関節モーメン トの大きな振動として現れてななららな接床と離床 を妨げる原因となっている。しかも虔屈モーメントの 発生がかなり遅れ，さらに，立脚期後半での底屈モー メントが不足して，体の前方移動のための push off が十分に行えていないことがわかる. 大煺切断者に， 健常者之同様の歩行を行方せるには，接床および離床 時の垂直床反力の振動の除去を行い，さらに，不足し ている足関節ま初りの底屈モーメントを補ってやる必 要がある．前者は，現在，広く用いられている粘弾性 材料を適切に選択することにより解洪できると考えら
れる、しかし，後者は，足関節の位置や踵部，つま先 部の粘弾性の程度を迨切に決めることにより, 立脚初 期の変形エネルギーを貯蔵して立脚後期に放出するこ とで，ある程度の足関節モーメントの補助は可能と考 えられるがの)，限度があり，本質的には，外部動力を 組込んた動力義足の方向へ進むよりほかに解決できな いと考えられる.

\section{5 下肢関節角度の微小振動}

微小振動の存在を 3.3 節で確認したが，本節では， それが何に起因するのかについて考察を加え，義足の 評価パラメータとしての応用の可能性について述べる.

得られた関節角度の貒小振動について，どの上うな 周波数成分であるかをみるために，スペクトル解析を 行った．健常者の関節角度について，元のデータから それを 11 点移動平均操作を2回くり返すことにより， 遮断周波数 $5.3[\mathrm{~Hz}]$ で高周波成分を除去して平滑化 したデータを差引くことにより微小振動のみを抽出し た結果を図 9 に示す。その扣のおのについて、フーリ 工級数展開により求めたパワースペクトルを，図 10 に示玄.この図から，いっそう，明瞭に， $\theta_{A}$ の微小

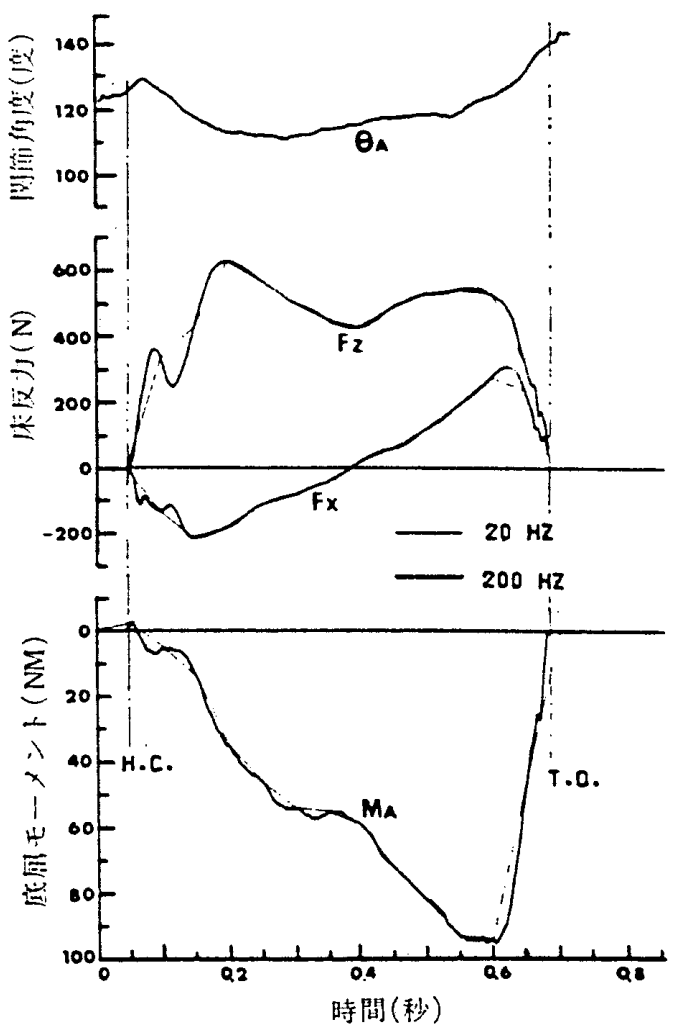

(b) 健常者

(a) 大腿切断者 義足側

图 8 立脚期の足関節モーメント. 


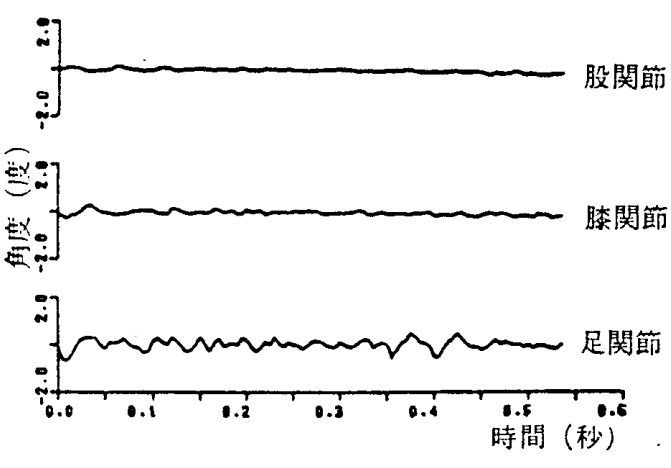

図 9 健常者の下肢関節角度の微小振動.

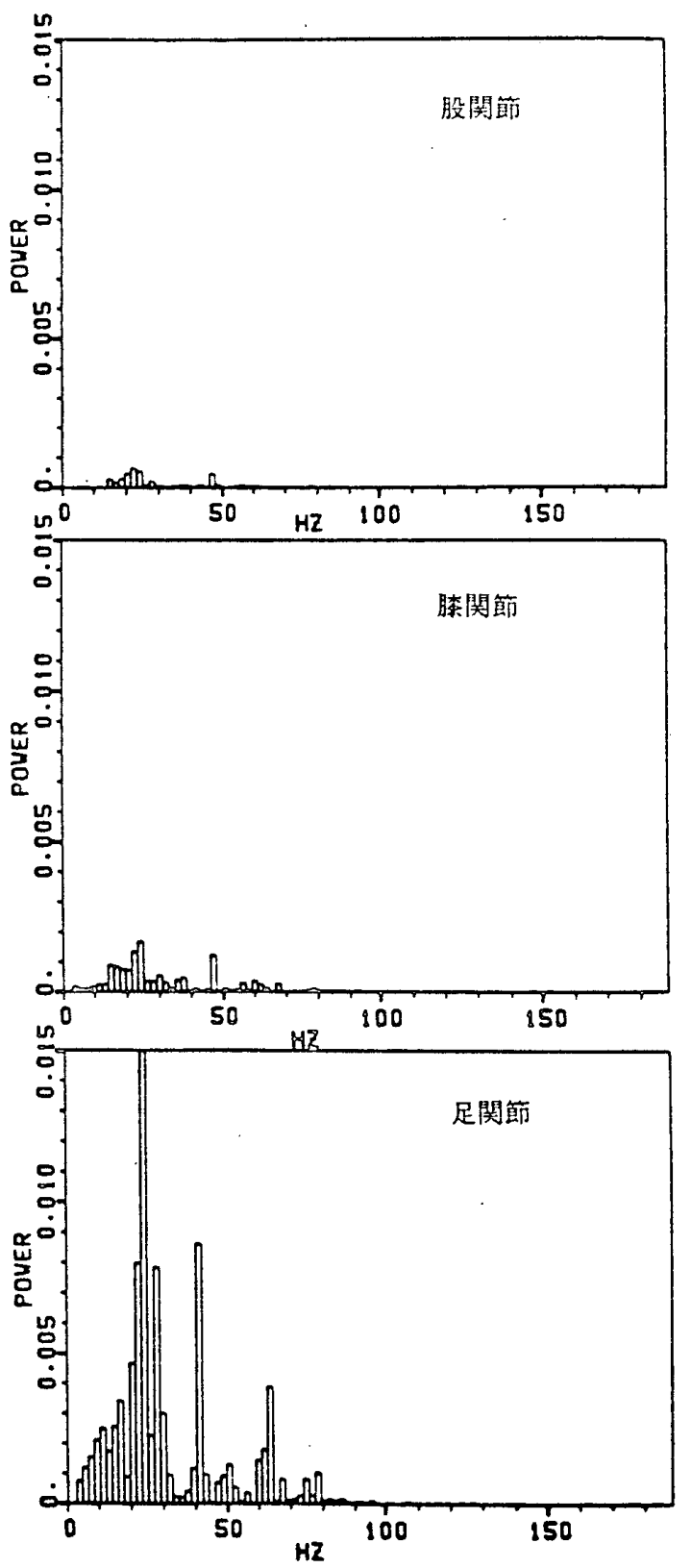

因 10 健常者の下肢関節角度の微小振動パワー スペクトル.

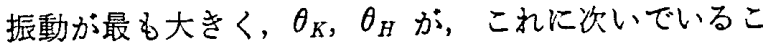
とがわかる.いずれも，20〜30[Hz] の近傍にピーク を有している。

敒小振動の原因としては，i）運動に固有の振動と， ii）生理学的要因による振動が考えられる.ところが， i）については，人間の片足立脚期を倒立振子とみる と, その固有振動数は約 $0.5[\mathrm{~Hz}]$ であり, 図 $10 \mathrm{~K}$ みられるよらな高い振動周波数の発生原因とは考えら れず，ii）の生理学的要因であると考えられる.

すなわち，足底より外界（地面）の情報をとり込み ながら，主働筋群と拮抗筋群との相互作用により足関 節を底背屈させて体重移動を行う際に, 両筋群の張力 の少なくとも一方に，伸張反射弓のフィードバック・ ループに起因する微小な振動が存在しで，これが足 関節トルクに微小振動を引き起こし，その結果，足関 節角度の微小振動が発生すると推定される。微小振動 の振幅の大きさが fine な制御の尽度を示すと仮定す れば，人間の下肢の場合も末梢况ど fine な制御が行 われていると言党，義足設計において，足関節を含む 足部の設計が重要な意味を持つことを示唆している.

運動中の生体に発生する微小振動に関して, 渡辺ら によれば，座位での下腿のゆっくりしたストローク運 動時に発生する微小振動の周波数は 6 8[Hz] であ りマ、これに較へてて，われわれの行った歩行運動中の 周波数は約 3 倍の高い周波数领域にある. ストローク 運動は主働筋のみの収縮現象であるが，步行荤動は， 表面筋電図により容易に観察できるごとく，主働笳の

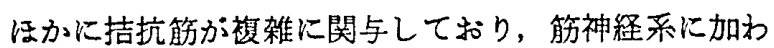
る負荷も大きく、ストローク運動に較べてより高い周 波数帯にピークを示すと考光られる．20３0[Hz]に ピークを示すことは, 永田らの, 下肢の屈伸運動時の 筋電図スペクトルが 20[Hz] にピークを示寸という報 告8)などからる，妥当と考えられる.この推論が正し ければ，足関節の運動に関与する筋神経系に加わる負 荷と, 足関節角度の微小振動のピーク周波数とは, 単 調增加の関倸にあることになり，さらに大きな負荷に 対しては，より高いピーク周波数を示すと考穴られる. 実際，步行運動上りも筋神経系に大きな負荷を与える と考えられる片足つま先立ら時の, 足関節角度の微小 振動を, 開始後約 1 秒間計測した結果では,ピーク周 波数は 20〜40[Hz] の近傍に存在した（図 11 参照). 次に, $\theta_{A}$ の微小振動について，健常者と大腿切断 者健足侧，大腿切断者義足側を比較するために，図 9 
166 バイオメカニズム—動倠の機蒂々制御—

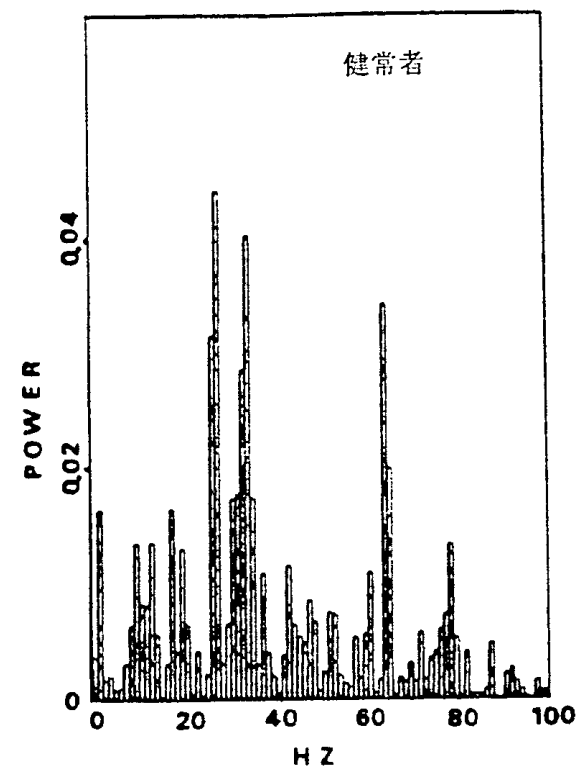

图 11 片足つま先立台時の足関節角度微 小振動の,パワースペクトル。

健学者

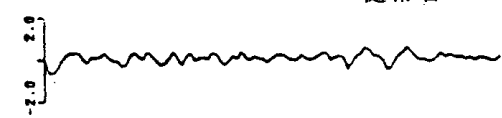

大腥切断老 義足僋

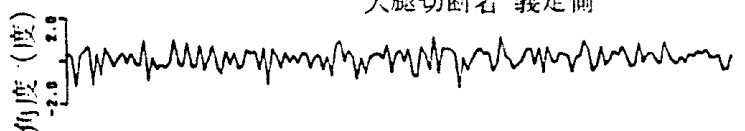

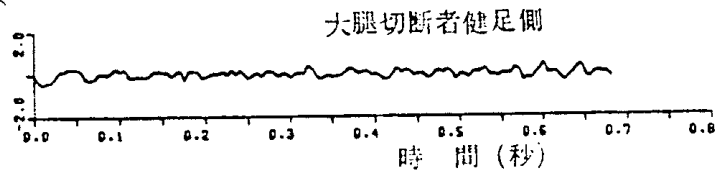

图 12 足関節争度の微小振動.

の場合と同じ方法で漄小振動のみを抽出した結果を， 因 12 に示す。これについて求めたパワースペクトル を㘠 13 に示す。この图より，さらに明瞭に，大眼切 断者健足侧，健常者，大腿切断者義足侧の塬に，大き なパワースペクトル成分を持っていることがわかる。 また，健常者の周波数スベクトルの最大ビークは，20 〜30[Hz] の間にあるが, 大腿切断者健足侧では20〜 $40[\mathrm{~Hz}]$ の間に存在する.大腿切断者健足側は，「のび 上り歩行」にみられるよらに，義足侧を補助して，か なりのパワーと制御を受持っており，たれが，微小振 動の大きな振幅と、より高い振動周波数として現れて いると考えられる。したがって，前にも述へたように， 運動の負荷と，関節角度の振動周波数および振幅との 関保は，ある単調堌加関数で表わされるようであり， 健足側に加わる負荷を足関節角度変動のパワースペク トル・パターンから調べて，義足の性能の評価を行ら
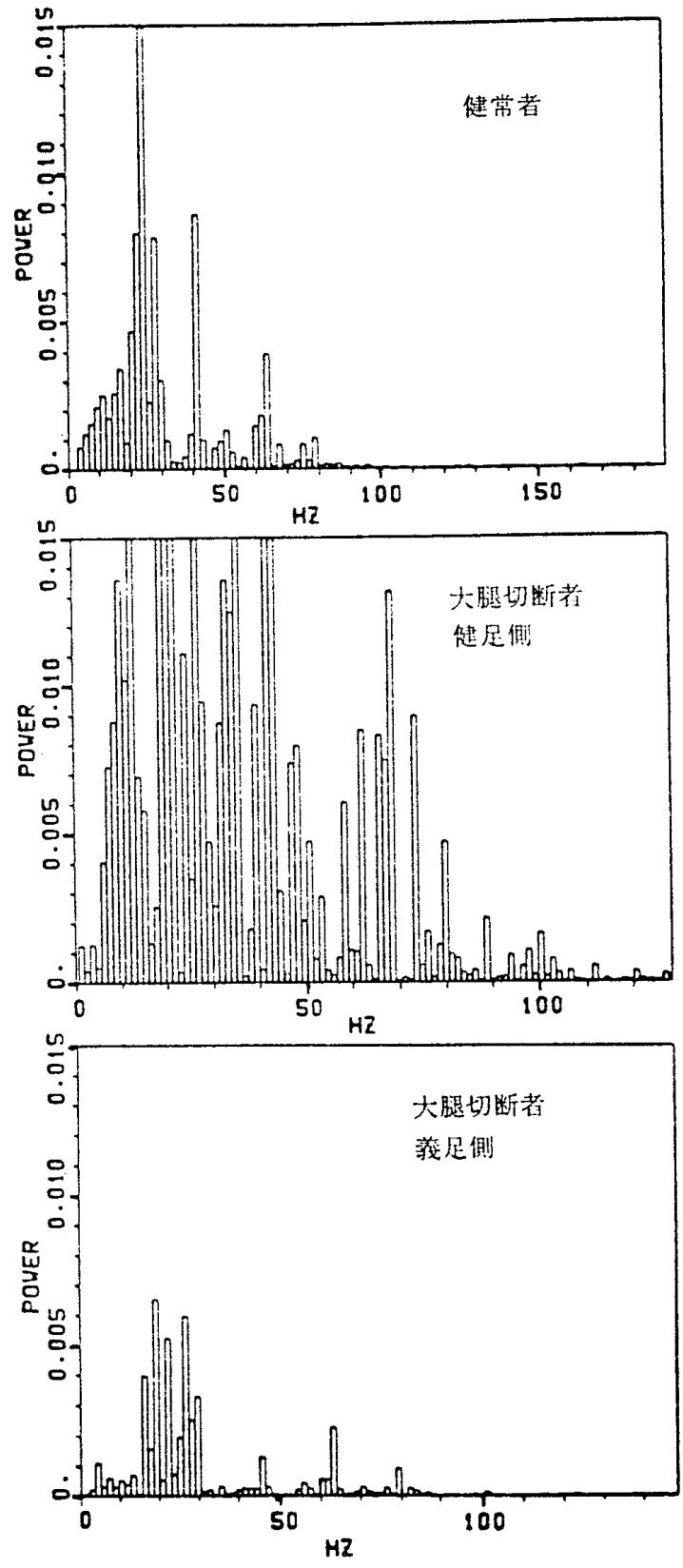

图 13 足関節估度微小振動のパワースペクトル。

ことが考えられる。

しかし，实際に判定規準として用いるには，また， 問題が多く残されている. 徽小振動の原因について, 生理学的に筋神経系に関する情報をより深くとら兄得 る筋電図の手法を，歩行分析システムと併用して，解 析を行い,さらに，冾噵レベルでの，主働筋群，拮抗 筋群の伸張反射弓を含さ制御モデルによる微小振動の 同定を行っていく必要があると考える.

4. 結論

義尼の設計のための基礎資料を得るため，時間スケ 
ールにおける高精度歩行分析システムを新しく構成し， 健常者および義足装着者の立脚期の動的挙動を, 主と して 200[Hz]で計測，比軟しな。乞の結果を，ステ イック・ピクチャー，下肢関節軌跡，下肢関節角度，

下肢関節モーメントについて整理し，従来の歩行分析 に用いられている 20[Hz] 程度のデータからはとらえ にくかった，種々の，足部を中心とする下肢の動的挙 動に関する知見を，200[Hz]データから得ることがで き，われわれの開発したシステムは，義足の設計に有 用な情報をもたらすことがわかった，例党ば，義足足 部の粘弾性材料の選択が適切でなかったために起こる 現象（接踵時のバゥンド，足関節モーメントの振動な

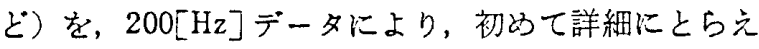
得た。

特に下肢関節角度については, 微小振動現象が観察 され，その原因を生理学的に考察して，主働筋群，拮 抗筋群の張力の少なくとも一方に, 伸張反射弓のフィ ードン゙ック・ループに由来する微小振動が存在し，そ れが関節トルクに微小振動を引き起こして, 関節角度 か微小振動すると推定した。この微小振動が末梢汪ど 大きいことから，歩行動作に执いて足䦭節が最も fine な制御を行っていることが推定され，義足設計におい ても，足関節を含む足部の設計が重要な意味を持つこ とが示嘫された：また，義足装着者の健足侧の足関節 角度か，健常者に較へて大きな微小振動振幅と高い振 動周波数を示す倾向がみられ，これらの振幅と周波数 の大きさか，足関節に加放る負荷の大きさと単調増加 の関倸を示すようであり, 義足の性能評価を, 健足側 の足関節角度の溦小振動のパワースペクトル。パター ンから行う可能性のあることが明らかとなった。

今後は，被騃者を增やしてデータの信賴性を高める と共に，足部の動的挙動を，より詳細に把握するうえ で， 3 次元計測を行う必要があと考えている。また， 足関節角度の微小振動現象の原因を，生理学的に，上 り深く筋神経系に関する情報をとらえ得る筋電図の手 法を用いて，検討を僬める予定である.

\section{参考文献}

1）例えば， B. Bresler and J.P.Frankel: “The Forces and Moments in the Leg during Walking", Trans. ASME., 72, (1950), 27.

2) 例兑法, S. R. Simon and S. D. Deutsch : “Genu Recurvatum in Spastic Cerebral Palsy, Report on Findings by Gait Analysis", J. Bone and Joint Surg., 60A-7, (1978), 882-893.

3) R.Drillis, R.Contini and M. Bluestein : "Body Segment Parameters, A Survey of Measurement Techniques", Artificial Limbs, 8-1, (1964), 44-66.

4) R. Contini : "Body Segment Parameters, Part II", Artificial Limbs, 16-1, (1972), 1-19.

5) 日井史郎：生体信号のディジタル微分処理の一方法につ いて, 電子通信学会, 医用電子・生体工学研究会資料, MBE 76-41, (1976), 13-18.

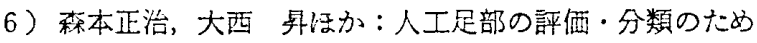
の機能計测システム，ハイオメカニズム 4, (1978), (1976)，213-221，柬京大学出版会.

7) 渡匄 瞭, 福本一郎ほか：ストローク運動時の四肢筋の 徵小掠動の分析，パイオメカニズム4，(1978），69-76， 東京大学出版会.

8）永田 戟, 室 增男, 北本 拓：餎収縮時の放電周波数 特性(第 2 報) 一一等張性表面筇電図の相関関数・フーリ 工解析一，体力科学，25，(1976)，28-36.

$9)$ O. Lippold : "Physical Tremor", Sci. Amer., Mar., (1971), 65-73.

付 録

空間來標に括ける，種々のサンプリング率での軌跡 の一例を，大腿切断者の健足側の小指球について付图 1に示す. 10 100[HZ] の軌跡は，200[HZ]の軌跡 を間引いて示してある。

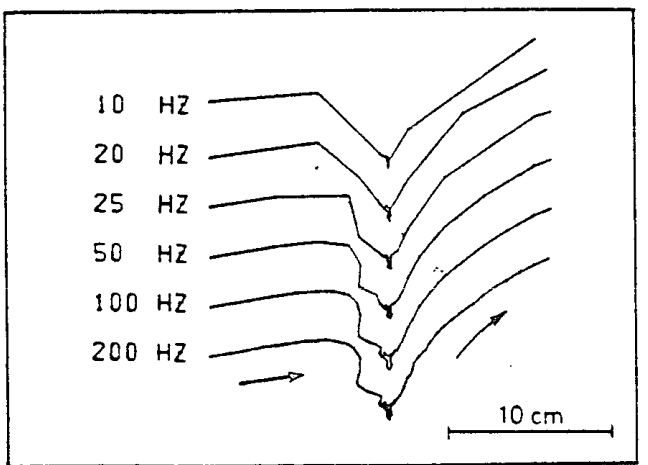

付因 1 大煺切断者健足侧の，種々のサンプリング 密に晾ける小指球軌跡。 